\title{
A humanidade schilleriana: um paraíso ideal encontrado
}

\author{
Bianka Teixeira de Andrade, UFMG
}

Resumo: Numa nota de Poesia ingênua e sentimental ${ }^{1}$, ao tratar do que chama de caráter realista e caráter idealista, Schiller atenta para o fato de estar combatendo a exclusão entre homem empírico e homem racional e argumenta que seu conceito de humanidade, ao contrário, inclui a ambos. Essa busca por integrar forma e matéria perpassa as conjecturas do filósofo tanto no livro supracitado, quanto nas cartas sobre $A$ educação estética do homem. As considerações que se seguem neste texto são uma tentativa de relacionar as duas obras tendo em vista as ideias do pensador acerca da formação (Bildung) do homem.

Palavras-chave: razão; natureza; cultura.

Mundo de beleza, onde estás? Regresse, primitiva e graciosa florescência da natureza!

Ah!, só na terra das fadas sobrevive

$\mathrm{O}$ vestígio fabuloso de tuas canções.

A campina sonha com os que se foram,

Meus olhos não contemplam nenhuma devoção.

Ah! daquele quadro quente de vida

só restaram as sombras.

Da terrível senda do Norte

caíram todos os botões.

Este mundo de deuses teve que perecer

em detrimento de um único deus. ${ }^{2}$

Esse poema em tom de lamento aproxima Schiller do poeta sentimental sobre o qual ele mesmo teoriza em sua Poesia ingênua e sentimental. Há nos versos a manifestação de um eu lírico que se perdeu da natureza e que, por estar detido ao mundo da abstração, a admira como um espectador que um dia integrou esse paraíso e agora tem consciência de que se perdeu dele. Apenas voltar a ser natureza, todavia, não parece ser o anseio do eu poético, pois já no primeiro verso evoca-se o mundo de beleza e a ideia schilleriana de belo, explicitada na Educação estética do homem, não seria nem mera forma, nem mera vida, mas, em seu sentido mais amplo, a forma viva ${ }^{3}$. Dito de outro modo, a beleza uniria em si o mundo racional e o mundo sensível, mesclaria os voos da abstração com as sensações que prendem o homem à matéria.

O homem forma viva seria, portanto, o homem belo, no qual atuam a "beleza suavizante" - que o aproxima de sua individualidade e do mundo sensível - e a "beleza enérgica" - que o aproxima da coletividade e do mundo da razão - sem coerção e dominação de uma sobre a outra. Unir forma e matéria, razão e sensação num movimento de atuação recíproca seria possível por meio do impulso lúdico, que joga tendo em vista o homem pleno e uno. 
Em sua análise sobre o que o Estado teria feito do homem, novamente percebemos o olhar melancólico e quase militante de Schiller (desta vez, o filósofo) para uma sociedade que tentou se desprender do mundo sensível para rumar em direção aos grandes ideais estabelecidos no mundo formal. O preço, segundo o pensador, foi demasiadamente alto, já que ao homem não é possível se desprender de sua matéria e um Estado que fundamenta suas leis tendo em vista apenas o bem coletivo paga caro por tentar suprimir a individualidade dos homens. Nessa sociedade enérgica e rígida, haveria surgido o alienado, o "bárbaro" ao qual Schiller opõe o selvagem. De um homem que era apenas natureza (como contam os mitos sobre os primórdios da cultura), formou-se um homem que se vê coagido a seguir o Ideal de uma coletividade com a qual não se identifica, pois tudo que lhe é individual deve ser suprimido para que se concretizem os grandes objetivos que visam o progresso da humanidade. Em contraposição a esse Estado que se estabeleceu em seu tempo, o filósofo propõe uma organização social que não esmague a individualidade do homem, pois

A razão pede unidade, mas a natureza quer multiplicidade, e o homem é solicitado por ambas as legislações. [...] Daí ser sempre testemunho de uma formação cultural ainda precária se o caráter ético só se afirma com o sacrifício do natural; e é ainda muito imperfeita uma constituição do Estado que só seja capaz de produzir unidade pela supressão da multiplicidade. O Estado não deve honrar apenas o caráter objetivo e genérico nos indivíduos, mas também o subjetivo e específico; não deve, ao ampliar o reino invisível dos costumes, despovoar o reino do fenômeno. ${ }^{4}$

O lamento do poeta e a crítica do filósofo se direcionam, então, à cultura que se estabeleceu alicerçada no princípio de que o mundo racional é mais nobre que o mundo do fenômeno. Para "consertar" esse sistema que sacrificou a individualidade do homem, Schiller propõe um retorno à natureza, mas, nesse retorno, o homem precisa levar consigo a liberdade que conquistou em suas incursões ao reino da razão. Mesmo os voos mais altos e perfeitos da abstração precisam se materializar nas limitações da experiência ${ }^{5}$, já que "o mecanismo vivo do Estado [...] precisa ser corrigido enquanto pulsa, as engrenagens são trocadas enquanto giram". ${ }^{6}$ Nesse girar incessante do tempo que se efetivam de uma forma limitada e imperfeita as possibilidades infinitas construídas no plano das Ideias. E o ideal de humanidade schilleriano, que deve se materializar enquanto o relógio do tempo pulsa, somente pode se concretizar "quando a vontade segue livremente a lei da necessidade e a razão afirma sua regra em toda alternância e fantasia". ${ }^{7}$

Assim como nas cartas sobre A educação estética do homem (concluídas em 1795), o que se percebe em Poesia ingênua e sentimental (que data de 1796) é a descrição de dois "perfis" de poeta/homem que, na verdade, deveriam estar unidos em apenas um: o poeta ingênuo, que é natureza e a integra, e o poeta sentimental, que lamenta em sua lírica o fato de estar do lado de fora do reino dos fenômenos. Ambos manifestam ingenuidade em seus textos, mas ingenuidades distintas: o ingênuo da surpresa e o ingênuo da intenção ${ }^{8}$, respectivamente. $\mathrm{O}$ primeiro estaria associado à ideia kantiana de ingenuidade, pois, em sua Crítica da Faculdade do Juízo, Kant a descreve como "a erupção da franqueza originariamente natural"9 e nela não haveria a incidência da consciência, ou seja, seria uma manifestação do agir humano puramente natural. Schiller, numa nota ${ }^{10}$, complementa que "o ingênuo da espécie mais nobre" não foi contemplado nas 
proposições de Kant e constrói, então, a ideia do ingênuo da intenção, que se revelaria na atitude consciente do homem de se voltar para a natureza. "Atribuímos a um homem uma intenção ingênua se em seus juízos não repara nas artificiais e rebuscadas relações das coisas e atém-se unicamente à natureza simples." 11

Diante do ingênuo da surpresa ${ }^{12}$, primeiramente, o homem de costumes e de sensibilidade sorri numa atitude de "escárnio jovial", mas em seguida sente uma comoção que mescla pesar e contentamento, o que converge com o conceito de sublime em Kant, pois despertaria um "movimento do ânimo sucessivamente em duas direções opostas"13. Ao perceber esse ingênuo na criança e no indivíduo de coração infantil ("objetos" nos quais tal ingênuo se manifesta, além também de tudo que é natureza pura), o homem moral se agitaria num sentimento de veneração - por enxergar neles o que um dia foi - e, concomitantemente, de melancolia - por ter consciência de que já não pode mais ser natureza pura. Na criança, o homem vê a potencialidade, enquanto ele já é realização, acabamento; na natureza, o homem enxerga o todo harmonizante que um dia foi, pois no mundo sensível impera apenas a lei da necessidade, enquanto no homem imperam as leis díspares da necessidade e do espírito.

A ideia schilleriana realmente não se limita a um retorno do homem ao seu estado natural, isso porque o mundo material é limitado e, portanto, submete o homem à cega privação e "tudo o que nasce da mera carência é desprezível" no caráter humano ${ }^{14}$. Simplesmente retornar ao paraíso e se submeter apenas às leis da necessidade seria abandonar a liberdade e o conhecimento que o homem conquistou no mundo das Ideias. Assim, as leis constituídas nos domínios da razão devem, mediante a vontade corajosa e o vivo sentimento, ir de encontro à sensibilidade e, para Schiller, essa é a grande lacuna de seu tempo, pois as conquistas dos ilustrados são por ele consideradas importantes, o grande problema é justamente o fato de tais conquistas terem sido obtidas através da supressão da sensibilidade. Se não rumarem em direção à vida, as grandiosas ideias estabelecidas no domínio da razão serão sempre utopias que fatalmente conduzirão à frustração daqueles que buscarem materializá-las. Manifestando sua preocupação com essa lacuna na formação (Bildung) do homem e enfatizando mais uma vez sua ideia de atuação recíproca entre impulso formal (entendimento) e material (sensibilidade), Schiller menciona que

A formação da sensibilidade é [...] a necessidade mais premente da época, não apenas porque ela vem a ser um meio de tornar o conhecimento melhorado eficaz para a vida, mas também porque desperta para a própria melhora do conhecimento. ${ }^{15}$

Essas considerações pressupõem também que, enquanto apenas coagido e governado pela necessidade e pela privação, não há espaço para o mundo das ideias. As necessidades do homem precisam ser supridas para que ele possa alçar seus voos ao mundo da abstração, "é a natureza que tem de ser satisfeita, antes que o espírito possa fazer uma exigência" $"$.

Nesses termos, a grande tarefa que resta, agora, à cultura (Bildung) é fazer das belezas a beleza. Harmonizar beleza enérgica - que impele o homem à permanência e à sua condição de pessoa por meio do impulso formal - e beleza suavizante - que constrange o homem à mutabilidade e à sua condição de estado através do impulso sensível. Os dois últimos versos do poema que antecedem as considerações aqui tecidas parecem se associar a essas ideias schillerianas de estado e pessoa, pois neles o eu lírico lamenta que "o mundo de deuses teve que perecer", afinal, não havia lugar para o homem em sua 
individualidade e naquilo que o diferencia da massa, não havia espaço para sua natureza mutável diante do propósito de restringi-lo à sua condição de pessoa, de ser moral que se firma em princípios imutáveis a serem observados pela coletividade. Imobilizado dentro dessa forma/fôrma, o homem sacrifica sua tendência dissolvente para seguir ao "único deus" imutável idealizado pelo Estado.

A razão redentora de Platão, que não deve ser iludida e desencaminhada pelos sentidos e que seria a luz direcionadora do homem às verdades de seu ser, acabou conduzindo-o ao desencantamento. ${ }^{17}$ Mas, em Schiller, é a razão que convida o homem a reatar com sua natureza e sua sensibilidade, pois, em nome da construção gloriosa de uma sociedade que acumula suas vitórias, muitas histórias individuais acabaram omitidas e esmagadas. Diante do fracasso nas tentativas de se encaixar a imaterialidade pura do mundo formal no mundo do fenômeno, resta reconhecer a ineficácia de um Ideal de humanidade que conduziu o indivíduo à barbárie, mais que isso, resta se valer dessa constatação para voltar a ajustar as engrenagens do relógio enquanto o tempo segue pulsando. Se a imaterialidade pura dos domínios da Ideia não conduziu a humanidade ao progresso glorioso que propunha, se o empreendimento de uma coletividade de esclarecidos falhou e acabou surrupiando e esmagando a individualidade, então a racionalidade precisa se conciliar com a materialidade do homem, materialidade esta que reafirma sua irremediável associação à natureza. Negligenciar isso é descuidar de algo que lhe é imanente, é silenciar o chamado do impulso sensível, que permanecerá sempre batendo à porta do homem.

O todo harmonizante que o homem observa na natureza já não é mais possível uma vez que ele fez suas incursões no plano formal, a unidade harmônica estabelecida no Ideal de humanidade puramente racional teve consequências catastróficas no Estado que se tentou estabelecer. Diante disso, resta propor um novo caminho e parece ser inadequado excluir uma das legislações pelas quais o homem é solicitado. Assim, de um Ideal de humanidade que prima pela razão pura, haveria que se construir outro que permita à sensibilidade o acesso em domínios formais. Num movimento recíproco, no qual a materialidade integra a racionalidade na construção de uma Ideia de homem possível na experiência, essa mesma Ideia deve sair de sua imaterialidade para se efetivar no mundo sensível. As infinitas potencialidades e possibilidades da razão precisariam, assim, abandonar o plano da mera abstração para fazer suas incursões no tempo e no espaço reais e imperfeitos. Essa ação recíproca é, para Schiller, o jogo, viabilizado pelo impulso lúdico, no qual o homem faz as pazes com suas faculdades. Em detrimento da humanidade bárbara que se constituiu, se efetivaria a humanidade bela, pois "A beleza é o produto da consonância entre o espírito e os sentidos, produto que fala simultaneamente a todas as faculdades do homem"18.

Nas proposições de Schiller, o caminho até essa humanidade bela deve ser trilhado via educação estética, ou seja, o instrumento que possibilitaria tal objetivo é a arte bela, a arte ingênua $e$ sentimental (que, concomitantemente, é natureza e dela se distancia para pensá-la), instrumento este que um Estado estruturado numa constituição bárbara não fornece por se alicerçar apenas em princípios da razão e por excluir a sensibilidade e a individualidade do sujeito. A beleza é, portanto, o grande Ideal proposto por Schiller e, ao mesmo tempo, o meio pelo qual esse objetivo deve ser perseguido. Nesse Ideal schilleriano, o homem, constitutivamente demandado tanto por seu impulso formal, como por seu impulso sensível, não deve ser nem animal racional, nem animal irracional, deve ser homem ${ }^{19}$.

A humanidade primitiva, na qual figurava o selvagem, e a humanidade de bárbaros, que são os intelectuais que se distanciaram da natureza, não satisfazem aos impulsos que 
constrangem o homem simultaneamente ao reino da razão e ao reino do fenômeno. No pensamento de Schiller, não há espaço para a exclusão de uma em detrimento da outra, por isso, a cultura teria como incumbência abrir os caminhos para a humanidade schilleriana, que busca o homem belo, o homem forma viva, o homem schillerianamente cultivado, o homem que é estado e pessoa, que é natureza e pensa a natureza, o homem ingênuo e sentimental, o realista e idealista, enfim, o homem que povoa o mundo sensível e, ao mesmo tempo, não deixou de exercer a liberdade que conquistou no domínio da abstração e dos costumes. O mundo de beleza evocado pelo poeta em seu primeiro verso parece se encontrar nas cartas sobre A educação estética do homem e na Poesia ingênua e sentimental. O caminho para se materializar esse paraíso encontrado por Schiller é sugerido em suas Ideias:

O botão da humanidade não floresce ali onde o homem se esconde nas cavernas como um troglodita, onde está eternamente só e jamais encontra a humanidade fora de si; nem ali onde, como um nômade, viaja em grandes massas, onde é eternamente apenas um número e jamais encontra a humanidade em si - mas só ali onde fala consigo mesmo ao recolher-se ao silêncio de sua cabana, e com toda a espécie, ao sair dela. ${ }^{20}$

Resumen: En una nota de la Poesia ingênua e sentimental (1991, p. 102), al tratar de lo que llama carácter realista y carácter idealista, Schiller pone de relieve el hecho de estar combatiendo la exclusión entre el hombre empírico y el hombre racional y argumenta que su concepto de la humanidade, por el contrario, incluye a ambos. Esta búsqueda de la integración de forma y materia impregna las conjeturas del filósofo tanto en el libro antes mencionado, como en las cartas sobre A educação estética do homem. Las consideraciones que siguen a este texto es un intento de relacionar las dos obras teniendo presentes las ideas del pensador acerca de la formación (Bildung) del hombre.

Palabras clave: razón; naturaleza; cultura.

\section{Referências Bibliográficas}

FREUD, Sigmund. O mal-estar na cultura. São Paulo: L\&PM Editores, 2010. 191 p.

KANT, Immanuel. Crítica da faculdade do juízo. 2. ed. Rio de Janeiro: Forense Universitária, 2010. 381 p.

KLEIST, Heinrich von. Sobre o teatro de marionetas. Disponível em: http:// www.acto.com.pt/acto/pdf/asmarionetas.pdf. Acesso em: 27 jul. 2012.

ROSA, Guimarães. Grande sertão: veredas. Rio de Janeiro: Nova Fronteira, 2006. 608 p. 
SCHILLER, Friedrich. A educação estética do homem. Trad. Roberto Schwarz; Márcio Suzuki. São Paulo: Iluminuras, 2010.

SCHILLER, Friedrich. Caderno de textos e poemas. [Simpósio Friedrich Schiller e a fundação do cânone da modernidade]. Org. por Izabela Maria Furtado Kestler. Rio de Janeiro: Faculdade de Letras/UFRJ, 2005.

SCHILLER, Friedrich. Poesia ingênua e sentimental. Trad. Márcio Suzuki. São Paulo: Iluminuras, $1991.150 \mathrm{p}$.

SCHILLER, Friedrich. Poesia ingenua y poesia sentimental. Trad. Juan Probst; Raimundo Lida. Buenos Aires: Coni, 1941. 122 p.

WEBER, Max. A ciência como vocação. Disponível em: http://www.lusosofia.net/ textos/weber_a_ciencia_como_vocacao.pdf. Acesso em: 27 jul. 2012.

\section{Notas}

${ }^{1}$ SCHILLER. Poesia ingênua e sentimental, p. 102.

${ }^{2}$ SCHILLER. Caderno de textos e poemas, p. 28.

${ }^{3}$ SCHILLER. A educação estética do homem, p. 73.

${ }^{4}$ SCHILLER. A educação estética do homem, p. 30.

${ }^{5}$ Cabe ressaltar que experiência aqui remete ao que é experimentável e experienciável no mundo sensível. Em contraponto ao reino das possibilidades e das potencialidades, a experiência é o lugar da vida material e efetiva, no qual tais possibilidades são experimentadas.

${ }^{6}$ SCHILLER. A educação estética do homem, p. 26.

${ }^{7}$ SCHILLER. Poesia ingênua e sentimental, p. 44.

${ }^{8} \mathrm{Na}$ tradução para o espanhol, encontra-se ingenuo del carater (SCHILLER. Poesia ingenua y poesia sentimental, p. 22).

${ }^{9}$ KANT. Crítica da faculdade do juízo, p. 180.

${ }^{10}$ SCHILLER. Poesia ingênua e sentimental, p. 46-47.

${ }^{11}$ SCHILLER. Poesia ingênua e sentimental, p. 49.

${ }^{12}$ No texto Sobre o teatro das marionetas, Kleist narra um episódio que parece ser uma manifestação do ingênuo da surpresa: num momento em que não lhe incidia a consciência/afetação, um jovem reproduz diante do narrador a imagem da estátua de um efebo que retira um espinho no pé. O jovem conta o fato a seu espectador e este ri dele. Quando tenta imitar a imagem conscientemente, o rapaz sente vergonha, pois já "Estava fora do estado de reproduzir esse movimento" (p. 05), o estado de pura natureza.

${ }^{13}$ KANT. Crítica da faculdade do juízo, p. 180.

${ }^{14}$ SCHILLER. Poesia ingênua e sentimental, p. 81.

15 SCHILLER. A educação estética do homem, p. 46, grifos nossos.

${ }^{16}$ SCHILLER. Poesia ingênua e sentimental, p. 98.

17 Esse sentimento em face da racionalização e da ideia de progresso que nela foi estabelecida aparece não apenas em Schiller, no século XVIII, mas também n'A ciência como vocação, de Weber, e n'O mal estar na cultura, de Freud, textos respectivamente dos séculos XIX e XX.

${ }^{18}$ SCHILLER. Poesia ingênua e sentimental, p. 98.

${ }^{19}$ SCHILLER. A educação estética do homem, p. 117-118.

${ }^{20}$ SCHILLER. A educação estética do homem, p. 123. 